\title{
ONDE SE ESCONDE O ESCRITOR?
}

WHERE DOES THE WRITER HIDE?

\section{¿DÓNDE SE OCULTA EL ESCRITOR?}

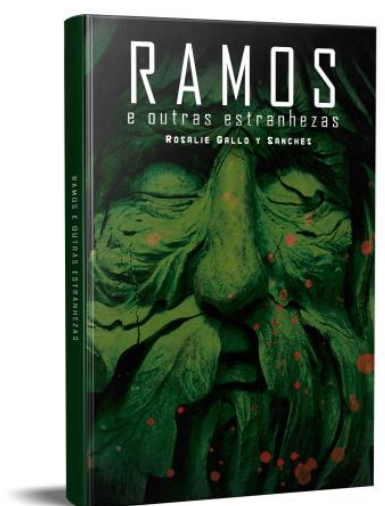

\footnotetext{
1. E-mail: rgallo1945@gmail.com. Doutora em Teoria Literária pelo Instituto de Biociências, Letras e Ciências Exatas da Universidade Estadual Paulista (UNESP). Dentre a sua vasta produção literária, em 2001, publicou no Brasil e na Itália "A Memória Invisível”, com fotos e textos sobre um cemitério genovês. Dois anos depois, veio o romance juvenil "Eu Vi Onde Termina o Mar", um dos selecionados na primeira edição do atual Programa Municipal "Nelson Seixas" de Fomento à Produção Cultural. O seu próximo livro de contos, "Ramos e outras estranhezas", está em fase de pré-lançamento na editora Mentes Abertas: https://mentesabertas.minhalojanouol.com.br/produto/329694/ramos-e-outras-estranhezas-[contos]
}

Recebido em: 12/04/2021

Aprovado em: 20/07/2021

Diante das várias teorias sobre a participação do autor na produção de seu texto, a pergunta que intitula estas reflexões pode parecer óbvia e simples. Advirto, porém, que não o é. Um texto oferece múltiplos esconderijos ao autor que usa de sua larga experiência, imaginação e poder criativo para andar nas linhas e entrelinhas do que produz.

Em meio aos vários elementos que compõem a narrativa (enredo, personagens, tempo, espaço, ambiente, narrador), o bom escritor passeia, melhor dizendo, perambula em sua criação tentando de forma consciente e, na maioria das vezes, se esconder. Inevitavelmente é descoberto pelos olhos do leitor atento que o detecta como se fosse portador de um mágico aparelho subjetivamente instalado em sua percepção aguda.

Assim, o escritor perambulante, andarilho das palavras, inicia sua peregrinação catártica textual tentando se esconder no elemento da narrativa com que mais rapidamente o leitor se identifica: a personagem. É por esta tentativa que começaremos a descobrir e fatalmente analisar a presença do autor no 
texto. Em outras abordagens e em próximos números desta revista acadêmica poderemos tratar de outros esconderijos.

Por ser a personagem o elemento da narrativa que pensa e age, tem vida própria e é capaz de decisões o escritor nela joga suas desilusões, suas esperanças, seus sonhos e realizações adiadas, suas tragédias pessoais e muitas das características emocionais que o atormentam. Entretanto, por ter a personagem necessidade de um corpo físico que o permita mostrar sua alma, o autor cria as personagens de seu texto com a maioria dos traços de si mesmo, principalmente se for um escritor principiante. Ao evoluir para um autor mais cuidadoso, buscará camuflagens: trocará os cabelos, a cor dos olhos, a estatura, o peso e, às vezes, o sexo.

A Psicanálise, assim como a Psicologia e a Antropologia, ao propor o estudo do texto literário em consonância com a vertente da corrente fenomenológica, busca no texto tudo o que se refere ao campo da simbologia e do imaginário. E é claro que a abordagem é válida. Como não dar às figuras de linguagem, em especial à metáfora, o devido valor instrumental a que se prestam todas elas para a produção textual? O texto literário, para que assim seja considerado, deve conter certo grau mínimo de literariedade estabelecido pelas escolas de Teoria Literária e alicerçado nas características fundamentais quais sejam a verossimilhança (não a cópia da realidade!), a universalidade e um potencial catártico que, somadas às tais características, oferecem ao leitor a possibilidade de se encontrar e se identificar no espelho autoral para usufruir a experiência que julga alheia.

Camuflar-se na personagem não é tão simples, pois, como dissemos. Os graus de complexidade para a construção de uma personagem variam ao infinito. Da projeção total autor/personagem à criação complexa de um autor que projeta partes suas em cada uma das personagens criadas em um uma única obra; da tentativa infantil de se esconder atrás de vícios que procuram ser infantil e inconscientemente minimizados à somatória analítica de toda uma obra de vida para se traçar o perfil, por fim, do próprio autor, as personagens trabalham para seu criador sem cessar.

Um exemplo clássico retrata em duas facetas o duelo íntimo entre o Bem e o Mal na obra de Robert Louis Stevenson, Strange Case of Dr. Jekyll and Mr. Hyde (O estranho caso do Dr. Jekyll e o Senhor Hyde) que se consagrou através não só de sua própria e estrondosa publicação em 1886, mas de diversas adaptações teatrais e cinematográficas. A começar pelo jogo de palavras dos nomes das personagens, temse uma gama extensa de possíveis interpretações: o perfil bom é doutor, social e intelectualmente superior; o perfil mau é apenas senhor, portanto, “inferior”. Jekyll foneticamente pode ser entendido como Jack ill (Jack/doente, mau, hostil, diabólico) e Jack kill (Jack/matança, matar, destruir, neutralizar por contraste). Hyde, por sua vez, foneticamente lembra hide, infinitivo do verbo esconder, ação apropriada para ocultar o mal; ao mesmo tempo, é o substantivo de língua inglesa que designa a pele, ou seja, o que cobre o ser 
animal, ou seja, o que esconde o interior, remetendo o leitor à ação anteriormente citada. Conotações nada aleatórias.

Outro clássico a ser lembrado é The Picture of Dorian Gray (O Retrato de Dorian Gray), escrito por Oscar Wilde, publicado em 1890 como folhetim e apenas em 1891 revisado, voltado à forma original e publicado como romance. Além do perfil psicológico do autor que se desesperava em administrar sua homossexualidade, a obra mostra a luta que existe no ser humano em busca da preservação da juventude e a rejeição à velhice que a destrói de forma inexorável; uma juventude que, retratada de forma magistral e negociada com a venda de sua alma, seria assegurada ao jovem Dorian Gray para continuar a desfrutar dos prazeres a que se habituara enquanto cabia ao retrato envelhecer. Mais uma vez, o embate dicotômico entre o Bem e o Mal, este aliado aqui ao culto da Beleza e da Sensualidade e agravado às últimas consequências. Também nada aleatória a escolha do nome Dorian, que remete a door (porta, passagem de abertura ou fechamento de espaços, meio de obtenção de algo) e ao sufixo inglês - ian que dá à palavra a que se liga sua ocupação como em magician (o que faz mágicas) ou se refere a profissão, como em physician (médico). Quanto ao sobrenome, é evidente a referência a grey (cinza), cor limite entre o branco e o preto, demarcando metaforicamente o território de cada lado: branco, da luz e preto, da escuridão da alma humana.

Se os títulos aqui citados são assim amplamente sugestivos, imagine o leitor o quanto os textos em si trarão de auxílio para seu prazer e conhecimento.

Vê-se, desta forma, o desdobramento do autor em mais de uma única personagem a demonstrar o prisma humano que cada um de nós é e em cujas facetas brilham, se giradas e expostas à claridade, os pelo menos dois lados de luz e sombra que o ser humano ainda cultiva em si em clima de batalha mortal.

É, pois, a personagem um excelente esconderijo, entre tantos que a narrativa permite para o autor inteligente que busca, a seu turno, um leitor inteligente para sua obra, um leitor capaz de desvendar seus mistérios e descobrir seus esconderijos, um leitor que aprecie sua criação. 